\title{
Disclosure of Audit Activities in Annual Reports: A Comparative Study of Selected Listed Companies in Botswana and South Africa
}

\author{
Gorata Onthatile Modirelabangwe ${ }^{1}$, Percy M. D. Phatshwane ${ }^{2}$ \\ ${ }^{1}$ Teaching Assistant, Department of Accounting and Finance, Faculty of Business, University of Botswana, \\ Botswana \\ ${ }^{2}$ Senior Lecturer, Department of Accounting and Finance, Faculty of Business, University of Botswana, \\ Botswana \\ Correspondence: Percy M. D. Phatshwane, Department of Accounting and Finance, Faculty of Business, \\ University of Botswana, P/ Bag UB 00701, Gaborone, Botswana.
}

Received: January 23, 2018

Accepted: March 7, 2018

Online Published: March 14, 2018

doi:10.5539/ibr.v11n5p1

URL: https://doi.org/10.5539/ibr.v11n5p1

\begin{abstract}
Audit activities form part of the key functions that enhance the reliability and validity of financial and non-financial information. One of the reporting processes investors and other stakeholders rely on when making decisions is the annual reports of enterprises which are a compilation of various reporting elements. Although internal auditors do not make direct disclosures in annual reports, many financial and non-financial disclosures are for audited items. Ultimately internally-audit activities and those of the external auditor are reflected in disclosures made by the internal audit function, the audit committee, and the external auditors themselves. The main objective of this study was to identify the levels of audit disclosure made in reference to the activities of IAFs, external auditor and the audit board committee, and to make comparisons therein between Botswana Stock Exchange (BSE) and the Johannesburg Stock Exchange (JSE) listed companies. To uncover the extent of these disclosures the current study derived seventeen (17) mandatory or voluntary audit disclosure areas that were used to conduct text analysis and to determine disclosures made for a cross-country study of three companies, each from the areas of retail, banking and insurance selected from the Botswana Stock Exchange (BSE) and the Johannesburg Stock Exchange (JSE). The study found that audit committees and internal audit functions dominated the disclosure of the audit-related variables, and that external auditors tend to confine their disclosure to areas concerned with presentation and qualification of financial statements. The study also found that companies listed in the JSE made more disclosures than their BSE counterparts, and that the retail sector made fewer disclosures as compared to the other two sectors. Furthermore, disclosures related to assessment and management risk as well as aspects of internal audit functions were the two most frequently disclosed variables in both geographic locations. The study goes on to recommend that future studies make more comparative studies by sector, geographic location, and to explore the use of a broader range of auditing variables.
\end{abstract}

Keywords: audited-related activities, annual report disclosures, listed companies, cross-country study

\section{Introduction}

Audit activities of an organization are critical in shaping the assurance model of an entity. Audit procedures are the independent examination of records and activities that ensure compliance with established organizational controls, policies and operational procedures (Basu, 2009). These financial compliance and probity functions were conventionally assumed by internal and external audit functions of organizations (Bosi \& Joy, 2017). Whilst internal auditing evaluates an organization's operations by personnel within the same organization (Almström \& Kinnander, 2011), external audit is the independent examination and expression of an opinion on the financial statements of an entity and risk therein by external professionals (Bediako-Ahoto, 2011). According to Soh and Martinov-Bennie (2011) the processes of external audit forms a smaller part of the audit process and therefore investors and other stakeholders often depend on the work of other organizational constituents when making decision regarding a particular organization (Chatterjee, Tooley, Fatseas \& Brown, 2011).

Over the past two decades the demand for greater levels of governance mechanisms by board directorship has 
further increased the scope of auditing functions in organizations (Bishop, DeZoort \& Hermanson, 2017). This is clearly evidenced by the growing corporate governance literature in financial control and auditing (Carcello, Hermanson \& Ye, 2011). Subsequently three monitoring mechanisms have been identified by the extant literature as driving the role of audit reporting in organizations namely, internal auditing, external auditing, and audit board committee (Al Matarneh, 2011).

Despite the growing understanding of auditing activities in developing countries, little is known about similar advances in developing countries. This is partly due to the dearth of literature on organizational accountability, transparency, and corporate governance practices in the developing world (Tsamenyi, Enninful-Adu \& Onumah, 2007). This study examines the levels of audit information disclosures in the annual reports of six selected listed companies in Botswana and South Africa as appreciated through reports made by various units of organizations on auditing activities, whether voluntary or mandatory.

\section{Literature Review}

\subsection{Organizational Accounting Structures, External Auditing and Audit Committees}

For many decades audit functions served an important role in assessing a company's activities against relevant standards and providing an opinion or information with regards to an organization. Internal audit activities are mainly concerned with ensuring that companies comply with internally set standards, that its operations are carried out efficiently, and that financial statements have been prepared correctly and accurately to ensure the reliability of such statements (Cooper, Chow \& Yun Wei, 2002). Internal audit functions (IAFs) are also expected to direct internal assurance planning and program execution, to deliver risk identification, and to develop monitoring and mitigation strategies (Staciokas \& Rupsys, 2005). Finally, they must report to the board on decisions taken, including approval of financial statements (Pratoomsuwan, 2012). In addition to IAFs, organizational accounting functions serve a larger role in the provision of financial and associated information, albeit with the support of the other internal organization constituents such as financial controllers. Ultimately internal auditors provide an important internal governance mechanism that is critical in shaping financial reports that are eventually published in annual reports. Although internal auditors do not make direct disclosures in annual reports of companies, the result of their audited activities form the basis of disclosures made by various persons associated with the organization (Saha \& Arifuzzaman, 2011). Therefore, as Arkermann, Marx and Fourie (2016) posit, IAF disclosures and evidence of their work therein can be traced to annual reports though references made on their work by other organizational constituents.

On the other hand external audit is the independent and objective verification of financial statements of an organization's, financial statement, combined with the expression of the auditor's opinion regarding the statements (Staciokas \& Rupsys, 2005). The intervention of the external auditor in the reporting process provides assurance on the authenticity of the financial statements. This process not only considers possible errors and fraudulent activities, but also pronounces on whether financial statements are presented fairly, and whether all information provided reflects actual transactions that occurred during the financial period (Chandler, Edwards, \& Anderson, 2012)

An audit committee is a delegate committee of the board of directors tasked with guaranteeing the reliability of accounting information provided by firms (Méndez \& García, 2007). Vafeas (2005) suggests that audit committees are responsible for monitoring information contained in financial reports. In addition, Méndez and García (2007) note that audit committees are essential to improving market transparency and restoring the investment community's confidence. Audit committees form part of the executive board of a firm and according to Vafeas (2005) they must be made up of financially literate people and atleast one must be a financial expert. Karamanou and Vafeas (2005) maintain that audit committees must be independent, thereby being free from management influence. The primary tasks of audit committees include the evaulation of companies' internal audit systems, safegaurding the independence of internal auditors and to evaluate and control the processes of corporate governance, information transparency and conflicts between managers and shareholders (Méndez \& García, 2007). However the sole presence of an audit committee does not guarantee sturdy financial reporting system since factors such as the company's ownership structure, leverage and industry sensitivity come into play (Habbash, 2015).

\subsection{Audit Expectation Gap}

The audit expectation gap is primarily concerned with the existence of differences in perceptions between the audit profession and the public regarding the nature, purpose and functions of those who engage in audit activities (Soh \& Martinov-Bennie, 2011; Bedard, Sutton, Arnold \& Phillips, 2012). A study by McEnroe and Martens (2001) found that investors have higher expectations for the various components of assurances of the 
audit-process than do auditors. Similarly, Dibia (2015) ascertained that users of financial statements hold different perceptions regarding the practice of audit, and that their perceptions of the work and assurance provided by the auditors are quite diverse. A study by Bedard, Sutton, Arnold and Phillips (2012) concurs, further disclosing that many investors believe that information provided in annual reports, not just the financial statements, is audited. In order for companies to help bridge the expectation gap, Epstein and Geiger (1994) suggest that the audit profession needs to embark on processes that will fundamentally change attitudes, and that will ultimately meet society's expectations in terms of reporting and provision of information. Furthermore, they suggest that an expansion of services which incorporates more work on fraud detection, internal control audits and disclosure levels are vital in bridging the gap.

Although the Bedard, Sutton, Arnold and Phillips (2012) study focuses on the investor's perception of whether various contents of annual reports were audited, a crucial element that is introduced as an extension of the expectation gap is the 'information gap' which can be found within annual reports. This phenomenon examines whether investors know about auditors' involvement with information contained in annual reports and whether, according to Hooks, Coy and Davey (2002), there is inadequate disclosure which results in an information gap between stakeholders and the disclosures provided by companies. The findings of various studies suggest that there is a difference in disclosure needs between two or more user groups on perceived information needs (see for example Wallace (1988); Mirshekary \& Saudagaran (2005); Hassan, Giorgioni, Romilly \& Power (2012); An, Davey, Eggleton \& Wang (2015). The findings of these studies identified low levels of disclosure in the developing countries where the studies were conducted, as well as a significant difference between actual disclosure practices of companies and market expectation of such practices.

While the debate around the expectation gap and its associated information gap continues, it has become a norm for companies to voluntary disclose information regarding their operations in annual reports as a means of bridging these gaps (Braam \& Borghans, 2014). In doing so more detailed information regarding a company's internal operations such as disclosures on its IAF and audit management issues are communicated within their annual reports. Audit disclosures are a means used to make the auditing process more transparent to users of financial reports (Doxey, 2013). As Phosrichan, Boonlua and Janjarasjit (2016) observe, audit disclosures promotes transparency and adds value to information disseminated to users of annual reports.

According to Depoers (2000), audit disclosure has significantly increased over the years, in particular the provision of information in areas required by regulation. In order to satisfy market information needs and provide information required for corporate transparency and accountability there is a consensus that business reporting models needs to expand beyond the traditional financial reporting model and be more forward-looking based on prospective information (AICPA, 1991 ${ }^{1}$; Beattie, McInnes \& Fearnley, 2004). However an increasing body of literature cautions against this practice due to risk factors associated with disclosure. Some posit that the role of accounting regulation in organization oversteps its mandate when extensive non-mandatory disclosures are made (Depoers, 2000; Archambeault, DeZoort \& Holt, 2008).

Yet a fundamental issue that is not addressed by the literature and by researchers is the nature and level of audit disclosures made by various audit functions in the organization. Turlea and Stefanescu (2009) suggest that the auditing profession and reporting therein has changed considerably in the public sector as a result of the increasing complexity of organizational activities, changes in national and international accounting regulations, as well as the growing importance of risk management issues. In the private sector such concerns are raised to include corporate governance, disclosure in the proxy statement of whether the audit committee had fulfilled its responsibilities (Rezaee, Olibe \& Minmier, 2003). To better understand and begin to close this 'accountability vacuum' Humphrey, Loft and Woods, (2009) suggest that audit information requires continued and contextual understanding, a mandate pursued by the current study.

\subsection{Audit Disclosure Practices in Botswana}

Botswana's financial reporting environment is dominated by the requirements of the Botswana Stock Exchange (BSE), a Financial Reporting Regulatory Authority, the Companies Act, the Botswana Institute of Chartered Accountants (BICA), the new Accountants Act, and the International Financial Reporting Standards (Kiyanga, Wingard \& Cronje, 2016). The Botswana Stock Exchange has developed its own Code of Best Practice on Corporate Governance which contain various audit reporting and responsibility clauses. Besides auditing ventures, the code provides guidelines to listed companies on corporate governance and accounting practices. Further to this, the Botswana Institute of Chartered Accountants Institute (BICA) has directed its members to

\footnotetext{
${ }^{1}$ This AICPA document is commonly referred to as the Jerkins Report.
} 
comply with International Financial Reporting Standards (IFRS), International Standards on Auditing and International Federation of Accountants (IFAC) and related codes of ethical practice. In 2010 The Financial Reporting Act was published. One of its primary mandates was the establishment of the Botswana Accountancy Oversight Authority (BAOA). The authority provides oversight to both accounting and auditing services, and guides the provision of financial and non-financial information by entities.

Despite the various and continued efforts by Botswana regulatory bodies to align its financial reporting practices with internationally accepted standards and codes of practice, studies maintain that there is room for improvement to the current supervisory provisions (Josiah, Themba \& Matenge, 2016; Kiyanga, Wingard \& Cronje, 2016; Phatshwane \& Mbekomize, 2017). Research into voluntary disclosures patterns of locally-based companies have also begun to emerge. A study by Rankokwane (2008) determined that there was improvement in the promotion and reporting of environmental accouting and audit activities. Similarly, Mbekomize and Wally-Dima (2013) recognized that social and environmental reporting exists in Botswana listed companies and public organizations. Kitindi, Magembe and Sethibe (2007) contend that the presentation of additional information in annual reports, especially non-financial information, has grown profoundly in recent years. Baliyan, Othata and Swami (2012) found that financial reporting by Botswana listed companies has become more complex, and that disclosure requirements appear to be empowering stakeholders in decision making processes.

The Kiyanga, Wingard and Cronje (2016) study found that the increase in the level of corporate disclosure varied from sector to sector, and that the information items differed across organizations. The study also established that integrated reporting was not practised by all companies included in the Botswana Stock Exchange (BSE) sample, and that companies listed on the South African Johannesburg Stock Exchange (JSE) had a higher level of corporate disclosure, and that internal audit and audit committee disclosure is more prevalent in South African listed companies. However the nature and areas of disclosures were not revealed by the study.

\subsection{Audit Disclosure Practices in South Africa}

The South African reporting environment is similar to that of Botswana in that both use the IFRS and the Kings III (or IV) Code of Corporate Governance. According to the World Economic Forum South Africa has a world class securities exchange system, and has been ranked $3^{\text {rd }}$ globally for regulations relating to securities exchanges compared to Botswana's $59^{\text {th }}$ ranking (World Economic Forum, Competitiveness Report of 2016 2017). Similarly, several studies assert that with the exception of the Johannesburg Stock Exchange (JSE), most African stock exchanges exhibit immature markets and poor market inefficiency (Mensah, 2003; Odera, 2012; Mobarek \& Mollah, 2016), presenting the JSE as a more advanced player in the global financial markets' sphere.

As is the case with Botswana, an expectation gap has been reported by studies conducted in the South African business environment. A study by Firer and Meth (1986) examined the information requirements of South African investment analysts and compared them with their UK counterparts. The study reported low levels of voluntary disclosure among South African firms in comparison with the UK group of companies included in the study. A subsequent study by McInnes (1994) disclosed that there are three areas that are the likely causes of insufficient disclosure. The areas identified are lack of independence of auditors, uncertainty regarding the role of auditors and the dissatisfaction with the compulsory audit of small owned businesses. More recently Kiyanga, Wingard and Cronje (2016) reported that voluntary audit disclosure in annual reports has increased considerably in South Africa since more users of financial information render the information more credible as a result of increased disclosure. This is further supported by Kiyanga (2014) who notes the increasing levels of disclosure by South African listed companies allows investors to make more informed decisions.

Following from these discussions, the primary objective of this study is to identify the levels of audit disclosure made in reference to the activities of IAFs, external auditor and the audit board committee. The study also seeks to make comparisons between companies listed on the BSE and those on the JSE, predominantly by the sector the company operates in. This will be accomplished by identifying audit disclosure in the annual reports of the selected companies, and classifying the disclosure according to the source of the disclosure (IAF, external auditor, or audit committee).

\section{Methodological Procedures}

\subsection{Justification of the Selection of BSE and JSE Listed Companies}

This study uses a qualitative research methodology under an interpretive paradigm as the research paradigm. The use of an interpretive involves the interpretation and reconciliation of different data using the researchers own subjective interpretation (Bhattacherjee, 2012). Interpretive paradigm is appropriate for the current study as it 
has the potential of generating new understanding on a concept not previously studied in the geographic and social domains covered by the study (Van Esch \& Van Esch, 2013). The study uses text analysis, a variant of content analysis, to systematically identify disclosure elements or characteristics from the data as outlined in table 2 below. Content analysis was selected for the study as it allows for large volumes of data contained in annual reports to be analysed. It is from these disclosures that inference is made by the study, albeit objectively and systematically, from the annual reports of companies selected for the study (Tregidga, Milne \& Lehman, 2012).

The selection of Botswana (BSE) and South Africa (JSE) as study subjects were motivated by both a desire to carry out a cross-country study, and the proximity and convenience of sourcing information from both sites. Furthermore, cross-comparison studies on disclosure patterns between the two geographic locations are common given the embedded economic and business associations that exist between the two countries (see for example Kiyanga, Wingard \& Cronje, 2016).

\subsection{Data Collection Procedures}

The current study is based on the premises that audit information disclosed in annual reports allows shareholders to access information on legal, financial and risk issues that relate to an organization and its environment. Besides information provision, these reports help keep management accountable for organizational practices and decision-making processes. Thus, the various constituents who provide audit information in annual reports will either be guided by prevailing legal, organizational, regulatory and industry practices.

The data that informed the study was collected from annual reports. Annual reports are a widely disseminated source of information by publicly held corporations, and therefore afford users easy access to corporate information (Arnold, Moizer, \& Noreen, 1984). Each annual report was subjected to qualitative content analysis to identify and classify auditing statements therein. For purposes of this study an auditing statement is a statement which refers to an auditing function or activity reported in the annual report. The study classified each statement by its source or provider, the three providers being IAFs, external auditor and the audit committee.

The population of the current study is all listed companies in BSE and JSE. As at June 2017 the JSE had 403 listed companies compared to the BSE with 46 listed companiesThe syudy uses listed companies because information related to these entities can be easily accessed online, and in both juristictions King III Code of Corporate Governance makes it mandatory for listed companies to present their annual reports at the end of each financial preriod to the general public. The sampling process was largely convenient with three relatively large listed companies listed in both the BSE and the JSE being selected for the study. To maintain some level of comparability two companies were selected from the financial sector (one in insurance and one in banking), and one from the retail sector in both countries. Although the sample is relatively small as compared to the population, the demands of an in-depth, longitudinal study was not amenable to the handling of a large corpus of data (Das, Verburg, Verbraeck \& Bonebakker, 2018).

The analysis of audit disclosures was conducted by reviewing the annual reports the six selected companies over a three-year period from 2013 to 2015 . Although the results of the study represent a tally of counts for all three years, comparisons were made between the various years for each company. Operational aspects of the selected companies are shown in Table 1. 
Table 1. BSE and JSE Listed Companies Selected for the Study

\begin{tabular}{|c|c|c|}
\hline Company & Operating Sector & Company Brief and Characteristics \\
\hline \multicolumn{3}{|l|}{ BSE Listed } \\
\hline Retail 1 & Retail & $\begin{array}{l}\text { A mass grocery retailer operating in Botswana and parts of Africa. } \\
\text { It is one of the largest retaiter stores operating in Botswana, and is } \\
\text { a mass employer. }\end{array}$ \\
\hline Insurance 1 & Financial / Insurance & $\begin{array}{l}\text { Established as a life insurance company listed on the BSE. The } \\
\text { company offers a range of savings, asset management and } \\
\text { employee benefits products. The company has been operating in } \\
\text { the country for many decades. }\end{array}$ \\
\hline Bank 1 & Financial / Banking & $\begin{array}{l}\text { The bank was registered in the } 1990 \text { 's and rapidly grew to become } \\
\text { one of the largest companies listed on the BSE. It has established } \\
\text { immense footprint in the country. }\end{array}$ \\
\hline \multicolumn{3}{|r|}{${ }^{-1}$} \\
\hline Retail 2 & Retail & $\begin{array}{l}\text { A South African food retailer established over half a century ago. } \\
\text { The group has presence in much of Africa and parts of Britain. }\end{array}$ \\
\hline Insurance 2 & Financial / Insurance & $\begin{array}{l}\text { The group offers a wide range of insurance, investment } \\
\text { management and related financial support services to its clients. It } \\
\text { has been operating in the country for many decades, and has } \\
\text { formidable footprint in the Southern African region. }\end{array}$ \\
\hline Bank 2 & Financial / Banking & $\begin{array}{l}\text { The bank is one of the largest banking groups in South Africa. It } \\
\text { offers wholesale and retail banking services, insurance, asset } \\
\text { management and wealth management services. }\end{array}$ \\
\hline
\end{tabular}

3.3 Classification and Coding of Data

Marston and Shrives (1991) found that many studies have measured disclosure quality, but there is no concrete explanation or general guideline for the selection of items to measure the extent of disclosure. In the current study the measurement of audit disclosure takes the form of a number of characteristics including words, sentences and paragraphs covering the various elements of audit-related disclosures (Unerman, 2000). Frequency counts were constructed from the codes in order to better understand the qualitative data. A total of seventeen (17) audit disclosure variables were identified from the perusal of BSE annual reports, and subsequently used for measurement purposes. These variables were either included in International Accounting Standards (ISA) guidelines, or formed part of the typical areas of organizational activities monitored by internal auditors (Robson, Macdonald, Gray, Van Eerd \& Bigelow, 2012). The variables identified for the study are provided in table 2. 
Table 2. Audit-related Disclosure Variables

\begin{tabular}{cl}
\hline Variable & Title / Name \\
\hline v1 & Assurance of the Report (Reasonable) \\
& \\
v2 & Independence of Audit and Auditors' independence
\end{tabular}

v3 Appointment of Auditors Name of Appointed Auditors

\section{Description}

Reasonable assurance is high level of assertion regarding the reliability of financial reporting and the preparation of financial statements for external purposes.

Independence refers to a state where the auditor is free form external influence regarding all audit procedures and the opinion given. External influences include shareholders, directors, management, and those who prepare or use the financial statements.

Generally appointment of auditors is done by the directors of the company if they were not already appointed at the Annual General meeting. In our analysis key themes include who appoints the auditors, who are the appointed auditors and the length of their appointment.

This variable answers the question 'who are the appointed auditors'.

This variable is set to uncover the specified responsibilities and duties of the audit committee, and whether they have been stated on the committee's report.

Risk assessment is estimating possible risks that may be involved with undertaking a particular activity. In contrast, risk management is concerned with the forecasting and evaluation of any financial risk and mitigation processes therein.

Internal controls refer to processes of assuring achievement of an organization's objectives in operational effectiveness and efficiency, reliable financial reporting and compliance with laws, regulations and policies.

These audits represent a process in which information is collected and assessed regarding the effeciency and effectiveness of the company's safety and health processes. These audits are commonly carried out by retail-type outlets. 

Report

v15 Audit Fees

Fair Presentation of Financial Statements (True and Fair View)
Compliance / conforming to International Standards of Auditors (ISA) and other regulatory bodies. This variable helps in establishing whether the selected companies comply with such (Stock Exchange, IFRS, KING Code of Corporate Governance, etc) An audit scope establishes how deep an audit is performed. Ordinarily not all financial aspects of a company are audited during each audit. The annual report is therefore required to communicate the scope of the audit.

Whether the financial statements are free from material misstatements or not. Therefore it must be stated on whether that opinion is unqualified, qualified, adverse, or a disclaimer of an opinion.

External auditor's responsibilities must be detailed in both in the auditor's and the director's report.

These variables are mainly concerned with the internal audit responsibilities and functions, in particular the different activities that fall under each function.

A report on responsibilities of internal auditor.

These fees are in the form of remuneration to the auditor for the services provided to their clients, however under this variable emphasis is not much on the amount is being paid but rather on whether such fees have been disclosed by the reporting company

Fair presentation refers to a financial reporting framework that requires compliance with the requirements of the framework and acknowledges explicitly and implicitly that it may be necessary for management to provide disclosures beyond those specifically required by the auditing reporting framework Misstatements that may affect the economic decisions of the users of financial statements. These misstatements could be due to fraud or errors. 


\section{Results and Discussions}

Annual reports of the six (6) selected enterprises listed in the BSE and the JSE for the years 2013 to 2015 provided the source of primary data analysed by this study. The 18 reports were used to generate the total observations for each company, with presentation of data and its analysis carried out on the basis of company location.

In presenting the findings tables were generated to show that level of auditing disclosure by individual companies and by stock listing (BSE or JSE).

\subsection{Botswana Stock Exchange Listed Companies}

The audit-related disclosure counts for the selected BSE companies were categorized based on the source of the disclosure (IAFs, external auditor and audit committee). The results are presented in table 3.

Table 3. Auditing Disclosure by Selected BSE Listed Companies

\begin{tabular}{|c|c|c|c|c|c|c|c|c|c|}
\hline \multirow[b]{2}{*}{ Variable } & \multicolumn{3}{|c|}{ Retail 1} & \multicolumn{3}{|c|}{ Insurance 1} & \multicolumn{3}{|c|}{ Bank 1} \\
\hline & IAF & $\mathrm{AC}$ & EA & IAF & $\mathrm{AC}$ & EA & IAF & $\mathrm{AC}$ & EA \\
\hline v1 & 2 & 6 & 4 & 8 & 11 & 4 & 2 & 3 & 3 \\
\hline $\mathrm{v} 2$ & 0 & 5 & 7 & 4 & 8 & 7 & 5 & 9 & 5 \\
\hline v3 & 0 & 4 & 0 & 1 & 9 & 0 & 0 & 3 & 0 \\
\hline $\mathrm{v} 4$ & 1 & 10 & 5 & 8 & 12 & 4 & 0 & 6 & 3 \\
\hline v5 & 1 & 14 & 0 & 1 & 63 & 0 & 0 & 18 & 4 \\
\hline v6 & 12 & 15 & 1 & 96 & 52 & 0 & 73 & 55 & 3 \\
\hline v7 & 8 & 13 & 2 & 9 & 8 & 5 & 23 & 26 & 6 \\
\hline v8 & 0 & 0 & 0 & 9 & 0 & 0 & 0 & 0 & 0 \\
\hline v9 & 2 & 9 & 2 & 27 & 35 & 0 & 10 & 18 & 0 \\
\hline $\mathrm{v} 10$ & 2 & 0 & 0 & 2 & 5 & 0 & 2 & 0 & 4 \\
\hline $\mathrm{v} 11$ & 2 & 4 & 13 & 0 & 5 & 11 & 0 & 2 & 20 \\
\hline v12 & 0 & 4 & 6 & 1 & 1 & 6 & 1 & 0 & 6 \\
\hline v13 & 0 & 20 & 2 & 11 & 19 & 3 & 6 & 10 & 0 \\
\hline v14 & 14 & 19 & 0 & 24 & 14 & 0 & 44 & 22 & 0 \\
\hline v15 & 6 & 1 & 0 & 3 & 0 & 0 & 6 & 1 & 0 \\
\hline v16 & 0 & 4 & 6 & 0 & 3 & 3 & 0 & 1 & 6 \\
\hline v17 & 0 & 3 & 5 & 0 & 1 & 1 & 0 & 2 & 7 \\
\hline Total & 50 & 131 & 53 & 204 & 246 & 44 & 172 & 176 & 67 \\
\hline Grand Total & \multicolumn{4}{|c|}{234} & \multicolumn{2}{|c|}{494} & \multicolumn{3}{|c|}{415} \\
\hline
\end{tabular}

Key: IAF -Internal Audit Function $\quad$ AC- Audit Committee $\quad$ EA - External Auditor

\section{Retail 1}

With a total of 234 disclosures over the three-year period, Retail 1 had the lowest level of disclosure of audit-related activities reported by the six companies include in the study. The audit committee is dominant in the overall level of disclosure of audit activities, followed by IAF. The low level of disclosure by IAF is likely due to the fact that for a long time Retail 1 did not operate an internal audit department. In 2014, the company introduced an internal audit unit to work alongside the audit committee. In fact, in 2013 there were no disclosures made by any IAF in relation to audit-related activities. In 2014 the IAF disclosures increased from zero to a little over twenty, increasing even further in 2015. Much of the audit-related information disclosed in 2015 referred to v13 (responsibilities of internal auditor) as a result of the newly established function. The study also determined that audit committee primarily disclosed on issues of assessment of risk management and internal audit functions and reports, whilst external auditors focus on the audit opinion.

Over the three year-period the company had the highest level of disclosure overall for variables such as assessment and management of risk (v6), the internal audit function and reports (v13 and v14), and internal controls (v7). On the other hand there were minimal disclosure on independence of audit and auditor's 
independence (v2), scope of the audit (v10), and safety audits (v8).

\section{Insurance 1}

Insurance 1 has all three audit functions active in audit-related disclosures. A summary of disclosures revealed that disclosures were mostly made by the audit committee (49\%) as compared the other two audit functions. The highest disclosure areas by the audit committee were statutory duties of the audit committee, followed by assessment and management of risk. The highest count for the internal audit functions was assessment and management of risk (v6). The company reported that it had recently adopted a risk assurance framework to define identify, assess, mitigate, and control risk. Such a strategy appears to have enhanced the disclosure of risk management. The next highest disclosure was the monitoring compliance to statutory bodies (v9), followed by v13 and v14 (responsibilities of internal auditor and reports thereof).

\section{Bank 1}

The results for Bank 1 indicated that the audit committee most prevalent in the disclosure of audit activities (42\%), followed by IAFs (41\%). Both units reported extensively on assessment and management of risk, internal controls, and internal audit functions. External audit disclosure were much lower than the other two functions, with most of its disclosures being in v11 (audit opinion).

In comparing the individual variables, v6 (assessment and management of risk) is the most disclosed variable by Bank 1 at $31 \%$ of total disclosures. It is worth noting that Bank 1 has a risk and compliance committee at board level. The committee is supported by a combined assurance forum made up of senior management and internal auditors. One of the priorities of this committee is ensuring that potential risk is identified, monitored and managed. This high disclosure and attention on risk is also improved by the fact that the company's annual report carries a separate report on risk management. The second most disclosed item is v14 (responsibilities of internal auditor report) accounting for $16 \%$ of disclosures, with v7 (internal controls) at 12\%. The least disclosed activities are v8 (safety audits), v3 (appointment of auditors) and v10 (scope of the audit).

The study noted that disclosure patterns over the three-year period between 2013 and 2015 are relatively similar. However the disclosure of v6 (assessment and management of risk) has the highest level of disclosure over all three years, and with the audit committees' view dominant in disclosures of the audit process.

\section{BSE Summary}

Overall the audit committee is more dominant in terms of disclosure of audit activities as compared to the other two functions. It accounts for almost half the disclosures made (48\%) as shown in table 4. External audit disclosures were mostly limited to issues of assurance and scope of the audit. Disclosures by Insurance 1 were the highest of all three BSE companies, with Retail 1 having the least disclosures in total for all 17 variables. Disclosure of audit activities has however grown over the three-year period, and it is therefore fair to conclude that audit disclosures are on the rise, and that voluntary disclosure areas are observed.

Table 4. Aggregated Total Results for the BSE Companies

\begin{tabular}{lcccc}
\hline Company & IAFs & Audit committee & $\begin{array}{c}\text { External } \\
\text { audit }\end{array}$ & Total \\
\hline Retail 1 & 50 & 131 & 53 & $\mathbf{2 3 4}$ \\
Insurance 1 & 149 & 242 & 103 & $\mathbf{4 9 4}$ \\
Bank 1 & 172 & 176 & 67 & $\mathbf{4 1 5}$ \\
Total & $\mathbf{3 7 1}$ & $\mathbf{5 4 9}$ & $\mathbf{2 2 3}$ & $\mathbf{1 1 4 3}$ \\
\hline
\end{tabular}

When it comes to disclosure frequency, v6 (assessment and management of risk), v14 (responsibilities of internal auditor report), v9 (monitoring compliance to regulatory bodies), v5 (statutory duties of the audit committee), and $\mathrm{v} 7$ (internal controls) appear in the top five most mentioned audit disclosures by the three companies as shown in table 5 . The frequently disclosed items all carry mandatory disclosure. Interestingly the retail company made much fewer disclosures of $\mathrm{v} 9$ (monitoring compliance to regulatory bodies) as compared to the other two companies. The least disclosed variable is v8 (safety and health audits) which has zero across the years in all three companies. This disclosure is made voluntarily. 
Table 5. Ranking of Most Cited Variables by BSE Companies

\begin{tabular}{llllll}
\hline Company & $\mathbf{1}^{\text {st }}$ & $\mathbf{2}^{\text {nd }}$ & $\mathbf{3}^{\text {rd }}$ & $\mathbf{4}^{\text {th }}$ & Least \\
\hline Retail 1 & V14 & V6 & V7 & V13 & V8 (with zero count) \\
Insurance 1 & V6 & V14 & V13 & V7 & V17 (with two count) \\
Bank 1 & V6 & V14 & V7 & V9 & V8 (with zero count) \\
\hline 4.2 Johannesburg Stock Exchange Listed Companies & & &
\end{tabular}

The audit disclosure counts for the three JSE companies were also categorized based on the variables and unit making the disclosure. The results are presented in table 6 .

Table 6. Auditing Disclosure by Selected JSE Listed Companies

\begin{tabular}{|c|c|c|c|c|c|c|c|c|c|}
\hline \multicolumn{3}{|c|}{ Retail 2} & \multicolumn{3}{|c|}{ Insurance 2} & \multicolumn{3}{|c|}{ Bank 2} & \multirow[b]{2}{*}{ EA } \\
\hline Variable & $I A F$ & $\mathrm{AC}$ & EA & $I A F$ & $\mathrm{AC}$ & EA & $I A F$ & $\mathrm{AC}$ & \\
\hline v1 & 0 & 0 & 3 & 8 & 11 & 4 & 0 & 1 & 4 \\
\hline v2 & 3 & 11 & 6 & 4 & 8 & 7 & 8 & 10 & 5 \\
\hline v3 & 0 & 23 & 0 & 1 & 9 & 0 & 0 & 19 & 0 \\
\hline v4 & 2 & 19 & 6 & 8 & 12 & 4 & 2 & 34 & 2 \\
\hline v5 & 2 & 17 & 2 & 1 & 63 & 0 & 1 & 19 & 1 \\
\hline v6 & 33 & 28 & 0 & 96 & 52 & 0 & 99 & 24 & 0 \\
\hline v7 & 7 & 11 & 9 & 9 & 8 & 5 & 21 & 20 & 5 \\
\hline v8 & 17 & 0 & 0 & 9 & 0 & 0 & 11 & 0 & 0 \\
\hline v9 & 19 & 8 & 0 & 27 & 35 & 0 & 16 & 31 & 0 \\
\hline v10 & 1 & 4 & 0 & 2 & 5 & 0 & 5 & 2 & 1 \\
\hline v11 & 0 & 2 & 18 & 0 & 5 & 11 & 0 & 2 & 7 \\
\hline v12 & 2 & 1 & 9 & 1 & 1 & 6 & 0 & 0 & 5 \\
\hline v13 & 8 & 37 & 0 & 11 & 19 & 3 & 22 & 49 & 9 \\
\hline v14 & 46 & 17 & 0 & 24 & 14 & 0 & 40 & 13 & 0 \\
\hline v15 & 7 & 4 & 0 & 3 & 0 & 0 & 2 & 11 & 0 \\
\hline v16 & 0 & 0 & 6 & 0 & 3 & 3 & 0 & 6 & 2 \\
\hline v17 & 0 & 3 & 9 & 0 & 1 & 1 & 0 & 2 & 8 \\
\hline Total & 147 & 185 & 68 & 204 & 246 & 44 & 227 & 243 & 49 \\
\hline Grand Total & & 40 & & & & & & & \\
\hline
\end{tabular}

Key: $\quad I A F-$ Internal audit functions

AC- Audit Committee EA- External Auditor

Retail 2

With a total of 400 audit disclosures observed, Retail 2 had the lowest count for the JSE companies covered by the study. The Retail 2 audit committee has the highest level of disclosure overall for the company as it recorded 185 counts (46\%) of disclosures. The audit committee primarily reports on v13 (responsibilities of internal auditor), v6 (assessment and management of risk) and v3 (appointment of auditors). IAFs mostly report on the functions of the internal function, assessment and management of risk, and monitoring compliance to regulatory bodies. In contrast, the external auditors reported mostly on the v11 (audit opinion), v12 (external auditors' responsibilities) and v17 (material misstatements).

The most disclosed variable for the company overall was v14 (responsibilities of internal auditor report) with 63 counts. This differs from all other companies included in the study since assessment and management of risk was their most observed variable overall for most organizations. Assessment and management of risk is the second most disclosed variable with 61 counts, followed by v13 (responsibilities of internal auditor) with 45 counts. The least disclosed variables are v1 (assurance of the report: reasonable assurance), v10 (scope of the audit), and v16 (fair presentation).

\section{Insurance 2}

Disclosure of auditing activities by Insurance 2 totalled 494 counts over the three-year period. Variables such as v6 (assessment and management of risk) with $30 \%$ of overall organizational counts, v5 (statutory duties of the audit committee) and v9 (monitoring compliance to regulatory bodies) had a high level of disclosure. Some variables recorded low levels of disclosure, including v17 (material misstatements), v15 (audit fees) and v10 (scope of the audit).

Of the three functions the audit committee was most dominant in the disclosure of audit activities, followed by IAFs and lastly the external audit function. Table 6 shows that out of the seventeen variables the audit committee recorded the highest values for eight of the variables, with its primary disclosures being in the areas of v6 (assessment and management of risk), v5 (the duties of the audit committee) and v9 (monitoring compliance to 
regulatory bodies). The IAFs also recorded high counts for v6 (assessment and management of risk, monitoring compliance to regulatory bodies, and internal audit function reports. In contrast, the external audit function recorded highest counts for two variables; auditor's opinion (v11) and external auditors' responsibilities (v12).

Over the period covered by the study, disclosure of audit activities at Insurance 2 reduced significantly. A variable such as assessment and management of risk had a count of 100 in 2013, reducing to 28 in 2014 and declined further to 20 counts in 2015. Internal controls had 19 counts in 2013, declining drastically to 1 count in 2014, and 2 counts in 2015. This differed in trends shown by other companies covered by the study since the general trajectory was an increase in the more 'popular' variables such as assessment and management of risk as the years progressed.

\section{Bank 2}

With a total of 519 disclosures over the three-year period, Bank 2 had the highest level of disclosure overall for all six companies covered by the study. Consistent with the observations made with regards to most companies included in this study, the audit committee is more prevalent in the disclosure of audit activities (47\%), with the IAFs accounting for $44 \%$ of disclosures made. The leading area of disclosure was v6 (assessment and management of risk), followed by v13 (responsibilities of internal auditor) and v14 (responsibilities of internal auditor reports). The audit committee recorded the highest level of disclosure for eight variables as compared the IAF with five leading variables. Again, the external audit function had the fewest disclosure counts.

The IAFs mainly focused on the reporting of v6 (assessment and management of risk), and v14 followed by v13 (responsibilities of internal auditor and their reports). The external auditors had its highest disclosure in the areas of monitoring compliance to regulatory bodies (v9), material misstatements (v17), and audit opinion (11).

In terms of the comparison in disclosure of the individual variables, risk assurance and management continues to be the most disclosed variable overall as compared to other variables, followed by the IAFs, and then monitoring compliance to regulatory bodies. This could be a result of the company operating in the financing sector which has strict compliance requirements. Variables such as v1 (assurance of the report), v10 (scope of the audit), v16 (fair presentation) and v11 (audit opinion) had the lowest overall levels of disclosure.

In this company the level of disclosure of audit activities over the three years has been at the same level. For example, a variable such as v7 (internal controls) recorded 16 counts in 2013, then 152014 and 2015. V2 (Audit independence) had 8 counts in 2013 and 2014, and 7 in 2015. However, v9 (monitoring compliance to regulatory bodies) and $\mathrm{v} 6$ (assessment and management of risk) showed an increase in counts as the years progressed.

\section{JSE Summary}

In the case of the JSE listed companies, audit committees disclosures were higher than the other two audit functions (48\%), although IAFs' disclosures are not far behind in comparison (41\%) as shown in table 7. Assessment and management of risk (v6) continues to be the most reported variable, particularly by IAFs. External auditors are rather confined to their role of giving their qualified opinion on the financial statements and less on other audit-related aspects. With the exception a few disclosure variables which decreased after 2013 for Insurance 2, audit disclosures have increased over the three years.

Table 7. Aggregated Total Results for Selected JSE Companies

\begin{tabular}{lcccc}
\hline Company & IAFs & Audit committee & $\begin{array}{c}\text { External } \\
\text { audit }\end{array}$ & Total \\
\hline Retail 2 & 147 & 185 & 68 & $\mathbf{4 0 0}$ \\
Insurance 2 & 204 & 246 & 44 & $\mathbf{4 9 4}$ \\
Bank 2 & 227 & 243 & 49 & $\mathbf{5 1 9}$ \\
Total & 578 & 674 & 161 & $\mathbf{1 4 1 3}$ \\
\hline
\end{tabular}

An analysis of overall disclosure patterns by all three companies revealed that v6 (assessment and management of risk) and v13 (responsibilities of internal auditor) are the two most audit disclosed variables as shown in table 8. They are followed by v14 (responsibilities of internal auditor report) and v9 (monitoring compliance to regulatory bodies). These highly reported items are all disclosed mandatorily. No discernable patterns emerged for the least disclosed variables. 
Table 8. Ranking of Most Cited Variables by Selected JSE Companies

\begin{tabular}{llllll}
\hline Company & $\mathbf{1}^{\text {st }}$ & $\mathbf{2}^{\text {nd }}$ & $\mathbf{3}^{\text {rd }}$ & $\mathbf{4}^{\text {th }}$ & Least \\
\hline Retail 2 & V14 & V6 & V13 & V4 & V1 (with 3 count) \\
Insurance 2 & V6 & V5 & V9 & V14 & V17 (with 2 counts) \\
Bank 2 & V6 & V13 & V14 & V9 & V1 and V12 ( 5 count each) \\
\hline
\end{tabular}

One of the exceptional features in the reporting of audit activities by South African companies was the detail with which disclosures were made on compliance to King III Code of Governance, Companies Act, and JSE listings requirements. Furthermore, the boards of the financial institutions studied had a functioning Group Risk Committee. This helped intensify disclosure of risk activities by board structures.

\section{Conclusion and Recommendations}

The main objective of this study was to assess audit disclosures made by selected BSE and JSE listed companies. This was achieved by coding audit disclosures using 17 codes of variables assigned to audit-related elements carried in annual reports. The findings of this study points to several interesting observations. The first is that when the results of both countries were compared in their entirety (all three companies), some audit disclosures pervaded the reporting process in annual reports. These include the assessment and management of risk, internal audit functions and reports, as well as monitoring compliance to regulatory bodies. All these areas carry mandatory disclosure. Notwithstanding, JSE listed companies carried more disclosures in total, as well as proportionate disclosure in the monitoring of compliance to regulatory bodies as compared to their BSE counterparts. This is consistent with the findings made by the Kiyanga, Wingard and Cronje (2016) study. However, somes area carried very low disclosure. In the case of the selescted BSE companies it was safety and health audits with no disclosures by two companies over the three-year period, and for JSE companies it was assurance of the report (reasonable), auditor's responsibilities, and material misrepresentations which, though carringing low disclosures, had some mention in some annual reports of all three companies over the three-year period.

The second observation is that some disclosures appear to follow industry practices. Companies in the retail sector, for example carried the least disclosures in each of the three companies selected countrywide, and for the 6 companies covered by the study. However, the retail companies were observant of mandatory areas of disclosure. Furthermore, the banks and insurance companies listed in both stock exchanges had a separate committee (internally or at executive board level) dedicated to risk monitoring, and /or had a separate report dedicated to risk management. Financial institutions also made more disclosures related to the requirements of regulatory bodies.

Thirdly, the majority of audit disclosures were made by IAFs and the audit committee, with very few disclosures being made by the external auditors. The role of external auditors appears to be that of building confidence in the financial statements and lending credibility to the company's reporting process. These findings suggest that the narrowing of the any information gap beyond the organization credibility largely falls on IAFs and the audit board committees. The need for board of directors to carry out their duties independently and diligently is crucial as they provide valuable information to stakeholders and extend accountability for the organization. As society and corporations grow, information disclosure patterns and responsibilities in audit activities require proficient people. The findings also support the establishment of appropriate board committees as a way of improving financial reporting and upholding good governance (Barako, Hancock \& Izan, 2006). This is particularly relevant to the BSE listed companies where audit committees (as opposed to IAFs) dominated the more popular disclosure areas such as assessment and management of risk.

Finally, when comparing total disclosures by geographic location, the JSE exceeds the counts for the BSE in all but 4 variables, namely assurance of the report (reasonable), internal controls, audit opinion, and fair presentation of financial statements. All these disclosures are mandatory, and can broadly be referred to as major facets of 'the traditional disclosure requirements in auditing'. In contrast, JSE selected companies exceeded their BSE counterparts more extensively in the disclosure of internal audit functions, the name of appointed auditor, monitoring and compliance to regulatory bodies, and safety and health audits.

While the findings of the study provide credence to the audit disclosure activities and the participation of various organizational constituents, there is need to recognize the implications of this study on the auditing and profession acumen expertise required for. The board audit committee is an important party in influencing audit disclosures, and in ensuring that regulatory requirements are upheld. Furthermore, stakeholders have certain expectations in regards to information that will be disclosed in annual reports. Thirdly, in both Botswana and 
South Africa there appears to be no concerted effort by board structures and organizational management in encouraging the reporting of voluntary audit information. In particular disclosures of safety and health, duties of the audit committee, and audit fee disclosure were poorly disclosed.

\section{Directions for Future Studies}

One of the limitations of the study is that audit variables have not been established by extant literature and were therefore developed for this study. Furthermore, the study could not assert the extent of audit activities involved with each variable in the organizations covered by the study since annual reports informed the study. More in-depth studies could refine areas of audit disclosure as defined here.

Although the study revealed some of the audit disclosures made by selected BSE and JSE listed companies, the reasons and motives for the disclosures could not be ascertained. Much broader and inclusive studies that incorporate more companies and industries may uncover more discernable audit disclosure patterns. It is also important for researchers to uncover and understand the information requirements and expectations of users of financial reports in order to appreciate the extent of any information gap in each geographic location, as well as in comparison with each other.

\section{References}

Ackermann, C., Marx, B., \& Fourie, H. (2016). Internal Audit Disclosures in Annual Reports of Metropolitan Municipalities in South Africa. Journal of Governance and Regulation, 5(1), 43-50. https://doi.org/10.22495/jgr_v5_i1_p6

Al Matarneh, G. F. (2011). Factors determining the internal audit quality in banks: Empirical Evidence from Jordan. International Research Journal of Finance and Economics, 73, 99-108.

Almström, P., \& Kinnander, A. (2011). The productivity potential assessment method: Assessing and benchmarking the improvement potential in manufacturing systems at shop-floor level. International Journal of Productivity and Performance Management, 60(7), 758-770. https://doi.org/10.1108/17410401111167825

American Institute of Certified Public Accountants (AICPA). (1991). Improving Business Reporting - A Customer Focus.

An, Y., Davey, H., Eggleton, I. R., \& Wang, Z. (2015). Intellectual capital disclosure and the information gap: Evidence from China. Advances in Accounting, 31(2), 179-187. https://doi.org/10.1016/j.adiac.2015.09.001

Archambeault, D. S., DeZoort, F. T., \& Holt, T. P. (2008). The Need for an Internal auditor Report to External Stakeholders to Improve Governance Transparency. Accounting Horizons, 22(4), 375-388. https://doi.org/10.2308/acch.2008.22.4.375

Arnold, J., Moizer, P., \& Noreen, E. (1984). Investment appraisal methods of financial analysts: a comparative study of US and UK practices. International Journal of Accounting, 19(2), 1-18.

Baliyan, P. S., Othata, O. O., \& Swami, B. N. (2012. Impact of Accounting Standards on Corporate Governance. A Case Study of a Few Selected Corporations in Botswana. Asian-African Journal of Economics \& Econometrics, 12(2), 421-433.

Barako, D. G., Hancock, P., \& Izan, H. Y. (2006). Factors influencing voluntary corporate disclosure by Kenyan companies. Corporate Governance; An International Review, 14(2), 107-125. https://doi.org/10.1111/j.1467-8683.2006.00491.x

Basu, S. K. (2009). Fundamentals of Auditing. Pearson Education India.

Beattie, V., McInnes, W., \& Fearnley, S. (2004). A methodology for analysing and evaluating narratives in annual reports: a comprehensive descriptive profile and metrics for disclosure quality attributes. Accounting Forum, 28(3), 205-236. https://doi.org/10.1016/j.accfor.2004.07.001

Bedard, J. C., Sutton, S. G., Arnold, V., \& Phillips, J. R. (2012). Another piece of the "expectations gap": What do investors know about auditor involvement with information in the annual report?. Current Issues in Auditing, 6(1), A17-A30. https://doi.org/10.2308/ciia-50120

Bediako-Ahoto, R. (2011). Determining the Effectiveness of Internal Auditing in Our Churches; The Case Study of the Presbyterian Church of Ghana Christ the King Congregation. International Journal for Management Science and Technology, 2(3), 25-30. 
Bhattacherjee, A. (2012). Social Science Research: Principles, Methods, and Practices. Second edition. CreateSpace Independent Publishing Platform.

Bishop, C. C., DeZoort, F. T., \& Hermanson, D. R. (2016). The Effect of CEO Social Influence Pressure and CFO Accounting Experience on CFO Financial Reporting Decisions. Auditing: A Journal of Practice \& Theory, 36(1), 21-41. https://doi.org/10.2308/ajpt-51507

Bosi, M. K., \& Joy, M. D. (2017). Issues and Challenges of Auditing In Islamic Financial Institutions. International Journal of Humanities and Social Science Invention, 6(2), 15-20.

Braam, G., \& Borghans, L. (2014). Board and auditor interlocks and voluntary disclosure in annual reports. Journal of Financial Reporting and Accounting, 12(2), 135-160. https://doi.org/10.1108/JFRA-11-2012-0054

Carcello, J. V., Hermanson, D. R., \& Ye, Z. (2011), Corporate governance research in accounting and auditing: insights, practice implications, and future research directions. Auditing: A Journal of Practice \& Theory, 30(3), 1-31. https://doi.org/10.2308/ajpt-10112

Chandler, R. A., Edwards, J. R., \& Anderson, M. (1993). Changing perceptions of the role of the company auditor, 1840-1940. Accounting and Business Research, 23(92), 443-459. https://doi.org/10.1080/00014788.1993.9729890

Chatterjee, B., Tooley, S., Fatseasa, V., \& Brown, A. (2011). An analysis of the qualitative characteristics of management commentary reporting by New Zealand companies. Australian Accounting Business and Finance Journal, 5(4), 43-64.

Cooper, B. J., Chow, L., \& Yun Wei, T. (2002). The development of auditing standards and the certified public accounting profession in China. Managerial Auditing Journal, 17(7), 383-389. https://doi.org/10.1108/02686900210437480

Das, P., Verburg, R., Verbraeck, A., \& Bonebakker, L. (2018). Barriers to innovation within large financial services firms: An in-depth study into disruptive and radical innovation projects at a bank. European Journal of Innovation Management, 21(1), 96-112. https://doi.org/10.1108/EJIM-03-2017-0028

Depoers, F. (2000). A cost benefit study of voluntary disclosure: Some empirical evidence from French listed companies. European Accounting Review, 9(2), 245-263. https://doi.org/10.1080/09638180050129891

Dibia, N. O. (2015). Audit Expectations Gap and Perception of Financial Reporting. International Journal of Managerial Studies and Research, 3(3), 23-31.

Doxey, M. M. (2013). The effect of increased audit disclosure on investors' perceptions of management, auditors,' and financial reporting: An experimental investigation. Unpublished Doctoral dissertation. University of Kentucky, USA.

Epstein, M. J., \& Geiger, M. A. (1994). Investor Views of Audit Assurance: Recent Evidence Of The Expectation Gap. Journal of Accountancy, 177, 60-66.

Firer, C., \& Meth, G. (1986). Information disclosure in annual reports in South Africa. Omega, 14(5), 373-382. https://doi.org/10.1016/0305-0483(86)90078-2

Habbash, M. (2015). Corporate governance, ownership, company structure and environmental disclosure; evidence from Saudi Arabia. Journal of Governance and Regulation, 4(4), 466-470. https://doi.org/10.22495/jgr_v4_i4_c4_p3

Hassan, O. A., Giorgioni G., Romilly, P., \& Power, D. M. (2012). The information gap in corporate annual reports: evidence from Egypt. African Journal of Accounting, Auditing and Finance, 1(4), 338-358. https://doi.org/10.1504/AJAAF.2012.052136

Hooks, J., Coy, D., \& Davey, H. (2002). The information gap in annual reports. Accounting, Auditing \& Accountability Journal, 15(4), 501-522. https://doi.org/10.1108/09513570210440577

Humphrey, C., Loft, A., \& Woods, M. (2009). The global audit profession and the international financial architecture: Understanding regulatory relationships at a time of financial crisis. Accounting, organizations and society, 34(6-7), 810-825. https://doi.org/10.1016/j.aos.2009.06.003

Josiah, J., Themba, G., \& Matenge, T. M. (2016). Corporate governance in Botswana: Exploring developments and compliance. Botswana Journal of Business, 9(1), 1-20.

Kitindi, E. G., Magembe, B. A. S., \& Sethibe, A. (2007). Lending decision making and financial information: the 
usefulness of corporate annual reports to lender in Botswana. International Journal of Applied Economics and Finance, 1(2), 55-60. https://doi.org/10.3923/ijaef.2007.55.66

Kiyanga, B. P. L. (2014). Corporate disclosure quality: A comparative study of Botswana and South Africa. Unpublished Master's Thesis, University of South Africa.

Kiyanga, B., Wingard, C., \& Cronje, C. (2016).Sustainability Reporting Practices:a comparative study of South African and Botswana Listed Companies. Studia Universitatis Babeș- Bolyai Negotia, LXI(2), 43-66.

Marston, C. L., \& Shrives, P. J. (1991). The use of disclosure indices in accounting research: a review article. The British Accounting Review, 23(3), 195-210. https://doi.org/10.1016/0890-8389(91)90080-L

Mbekomize, C. J., \& Wally-Dima, L. (2013). Social and environmental disclosure by Parastatals and companies listed on the Botswana stock exchange. Journal of Management and Sustainability, 3(3), 66-75. https://doi.org/10.5539/jms.v3n3p66

McEnroe, J. E., \& Martens, S. C. (2001). Auditors' and investors' perceptions of the "expectation gap". Accounting Horizons, 15(4), 345-358. https://doi.org/10.2308/acch.2001.15.4.345

McInnes, W. M. (1994). The audit expectation gap in the Republic of South Africa. Accounting and Business Research, 24(95), 282-283.

Méndez, C. F., \& García, R. A. (2007). The effects of ownership structure and board composition on the audit committee meeting frequency: Spanish evidence. Corporate Governance: An International Review, 15(5), 909-922. https://doi.org/10.1111/j.1467-8683.2007.00619.x

Mensah, S. (2003). The Essentials of an Efficient Market and Implications for Investors, Firms and Regulators UNECA Workshop on African Capital Markets Development, Johannesburg, SA. 27-29 October, 2003 .

Mirshekary, S., \& Saudagaran, S. M. (2005). Perceptions and characteristics of financial statement users in developing countries: Evidence from Iran. Journal of International Accounting, Auditing and Taxation, 14(1), 33-54. https://doi.org/10.1016/j.intaccaudtax.2005.01.001

Mobarek, A., \& Mollah, S. (2016). Global Stock Market Integration: Co-Movement, Crises, and Efficiency in Developed and Emerging Markets. Palgrave, Macmillan. https://doi.org/10.1057/9781137367549

Odera, O. (2012). Theoretical Issues in the African Stock Markets and Portfolio Performance. Journal of Economics and International Finance, 4(5), 19-28.

Phatshwane, P. M., \& Mbekomize, C. J. (2017). The History and Development Of Accounting: An Emphasis On Botswana. Botswana Journal of Business, 10(1), 1-37.

Phosrichan, N., Boonlua, S., \& Janjarasjit, S. (2016). Audit Review Integration Competency and Audit Success: An Empirical Investigation. BU Academic Review, 15(2), 161-176.

Pratoomsuwan, T. (2012). The effect of an audit firm's brand on security pricing. International Journal of Emerging Markets, 7(4), 430-442. https://doi.org/10.1108/17468801211264333

Rezaee, Z., Olibe, K. O., \& Minmier, G. (2003). Improving corporate governance: The role of audit committee disclosures. Managerial Auditing Journal, 18(6/7), 530-537. https://doi.org/10.1108/02686900310482669

Robson, L. S., Macdonald, S., Gray, G. C., Van Eerd, D. L., \& Bigelow, P. L. (2012). A descriptive study of the OHS management auditing methods used by public sector organizations conducting audits of workplaces: Implications for audit reliability and validity. Safety science, 50(2), 181-189. https://doi.org/10.1016/j.ssci.2011.08.006

Saha, A. K., \& Arifuzzaman, S. M. (2011). Management Disclosures on Internal Control in Annual Reports-A Study on Banking Sector: Bangladesh Perspective. International Journal of Economics and Finance, 3(5), 216-222. https://doi.org/10.5539/ijef.v3n5p216

Soh, D. S., \& Martinov-Bennie, N. (2011). The internal audit function: Perceptions of internal audit roles, effectiveness and evaluation. Managerial Auditing Journal, 26(7), 605-622. https://doi.org/10.1108/02686901111151332

Staciokas, R., \& Rupsys, R. (2005). Internal audit and its role in organizational government. Management of Organizations: Systematic Research, 33, 169-180.

Tregidga, H., Milne, M., \& Lehman, G. (2012). Analyzing the quality, meaning and accountability of organizational reporting and communication: Directions for future research. Accounting Forum, 36(3), 223-230. https://doi.org/10.1016/j.accfor.2012.07.001 
Tsamenyi, M., Enninful-Adu, E., \& Onumah, J. (2007). Disclosure and corporate governance in developing countries: Evidence from Ghana. Managerial Auditing Journal,22(3), 319-334. https://doi.org/10.1108/02686900710733170

Turlea, E., \& Stefanescu, A. (2009). Internal audit and risk management in public sector entities, between tradition and actuality. Annales Universitatis Apulensis: Series Oeconomica, 11(1), 210-217.

Unerman, J. (2000). Methodological issues-Reflections on quantification in corporate social reporting content analysis. Accounting, Auditing \& Accountability Journal, 13(5), 667-681. https://doi.org/10.1108/09513570010353756

Vafeas, N. (2005). Audit committees, boards, and the quality of reported earnings. Contemporary accounting research, 22(4), 1093-1122. https://doi.org/10.1506/1QYN-2RFQ-FKYX-XP84

Van Esch, P., \& Van Esch, L. J. (2013). Justification of a qualitative methodology to investigate the emerging concept: The dimensions of religion as underpinning constructs for mass media social marketing campaigns. Journal of Business Theory and Practice, 1(2), 214-243. https://doi.org/10.22158/jbtp.v1n2p214

Wallace, R. S. O. (1988). International and International Consensus on the Importance of Disclosure Items in Financial Reports: A Nigerian Case Study, British Accounting Review, 20, 223-265. https://doi.org/10.1016/0890-8389(88)90076-5

World Economic Forum, Competitiveness Report of 2016-2017, http://www3.weforum.org/docs/GCR2016-2017/05FullReport/TheGlobalCompetitivenessReport2016-2017 _FINAL.pdf. Accessed 20th June 2017

\section{Copyrights}

Copyright for this article is retained by the author(s), with first publication rights granted to the journal.

This is an open-access article distributed under the terms and conditions of the Creative Commons Attribution license (http://creativecommons.org/licenses/by/4.0/). 